\title{
Mā'ohi Travellers before 1825 and new insights from shipping lists
}

\section{Rhys Richards}

\section{(2) OpenEdition}

\section{Journals}

Édition électronique

URL : http://journals.openedition.org/jso/6170

DOI : $10.4000 /$ jso.6170

ISSN : 1760-7256

\section{Éditeur}

Société des océanistes

\section{Édition imprimée}

Date de publication : 15 décembre 2010

Pagination : 235-240

ISBN : 978-2-85430-027-7

ISSN : 0300-953x

\section{Référence électronique}

Rhys Richards, "Mā'ohi Travellers before 1825 and new insights from shipping lists », Journal de la Société des Océanistes [En ligne], 130-131 | 2010, mis en ligne le 15 décembre 2010, consulté le 24 septembre 2020. URL : http://journals.openedition.org/jso/6170 ; DOI : https://doi.org/10.4000/jso 6170 


\title{
Mā'ohi Travellers before 1825 and new insights from shipping lists
}

by

\author{
Rhys RICHARDS*
}

A recent list of all the ships that arrived at Tahiti and the Society Islands up to 1852 might well seem an unlikely place to look for drama and romance. Yet its preparation has shown that hundreds of Mā'ohi (Tahitian) people chose to travel far from home before 1825 (Richards and Langdon, 2008.). Unfortunately this list of foreign vessels reads rather like a telephone book: all names but no plot! Another limitation is that such a list tends to perpetuate nonindigenous, colonial, perspectives of Pacific maritime histories. However if we can draw out of these rather tedious ship lists and their quantitative statistics, something that opens our eyes to new perspectives, and to new ways of looking at the earliest periods of contacts between Polynesian people and Europeans, then certainly these shipping arrivals and departures lists will have been worth the considerable efforts made to make them, and to make them readily available (e.g. Cumpston, 1964; Langdon, 1978, 1979, 1984; Nicholson, 1977-1988; Richards, 2000).

Making this latest list has revealed a lot of information about Mā'ohi travellers. Only those Mà'ohi who were involved in special acts, such as bravery, misfortune or death, generated some historical record, and unfortunately these references are brief. Not very much can be said about them individually, but fortunately rather more can be said about them collectively. The scattered records show 230 Mā'ohi went away on foreign vessels before 1825 . There were certainly many more - perhaps twice as many, in total some three or four or five hundred. With so many of their young men gone away with the foreigners, the social impact must have been considerable. Then consider the effects when a few of these travelling Mā'ohi returned home ablaze with new facts, new technologies and new ideas! So this short review will provide first a few notes on some of the Mā'ohi on the new list, and then comment briefly on new perspectives that have emerged.

As is well known, the first 'Otahitian' to visit Europe, was Ahutoru, who went with Bougainville in 1768. Next in 1769 Captain Cook took away with him the priest and navigator, Tupuia of Rai'atea, along with his servant boy Tayeto. Alas, both died soon after that in Indonesia. Similarly Cook and Forster took Mahine on the Resolution to several island groups, including Easter Island, but Mahine declined to go on to England. The most famous Tahitian traveller was a commoner, Omai of Rai'atea, who travelled with Captain Cook to England and back in 1774 to 1777.

Less well known is Hitihiti of Borabora, who spent seven months with Captain Cook on his second voyage, visiting Tahiti, Ra'iatea and Huahine. By then Hitihiti spoke better English than Omai who had been to London. However Hitihiti chose to travel no further with Cook, and returned to Tahiti. There he met Bligh in 1788, went to Rarotonga and Tubuai with the Bounty mutineers in 1789 and was back living at Tahiti when Bligh returned in 1792. David Chappell in his excellent book about early Pacific travellers on foreign vessels, suggests that Hiti-

*mrhys@paradise.net.nz 
hiti remained at Tahiti until 1824 when he was the dignified man of about 70 whom Kotzebue met and mentioned but did not name (Chappell, 1996: 143).

Consider carefully the impact such an experienced survivor as Hitihiti could have had at Tahiti not only on among the visitors, but far more importantly among his Mā'ohi supporters. In 1774 two captive Mā'ohi, a man named Pautu and a young boy Tetua-nui, returned home from Lima and Valparaiso. They wore Spanish clothes, spoke Spanish and helped interpret for two padres. In 1775 the Spanish took eight Tahitians to Lima, but despite good treatment, seven died soon after their arrival at Lima, including one named Tipitipia (Corney, 1919, vol. I: 9-15, vol. II: 1-4). In 1797 the mission ship Duff took away several 'Otahitians,' including Tano Manu, Tom and Harra-we-ia (Wilson, 1799). What became of them is, alas, unknown. In 1792 Captain Bligh took away Mahiti, but he died in London, and his servant Pappo, who was also known as 'Jacket,' died at Jamaica (The Times, London, 5 September 1793; Bligh, 1792). Thirty years later Moe, then known as 'Jack Bligh,' was described as a cunning old fellow who spoke some English and was then an advisor to Queen Ka'ahu-manu in Hawai'i. Moe claimed that he had been aboard the Bounty during the mutiny in 1789 (Sydney Gazette 1 January 1824; Maccrea, 1922: 22).

In 1801 while returning from obtaining pork at Tahiti, Turnbull called at Norfolk Island. A Mă'ohi on his ship who landed there, proudly dressed in fine Tahitian tapa cloth, was astonished to meet on shore a compatriot called Oreo, who was smartly dressed as an English sailor. Oreo had apparently arrived first in Sydney in 1796, and then worked his way to England and back on the Albion (Turnbull, 1805; Cumpston, 1964 : 36-38). As early as 1804 he was classed as a free settler. By 1812 'Richetto Orio' held 3 1/2 acres under wheat and maize (Wright, 1986: 28).

From 1805 to 1813 the official 'beachmaster' on Norfolk Island was John Drummond who had a Tahitian servant whom he rather quaintly named John Drummond. When they both left Norfolk Island to resettle at the Derwent, John Drummond and Richetto Orio were the first Tahitians to live in Tasmania (Wright, 1986: 28).

Meanwhile Tapeooe (also known as Tapuoe) had left Tahiti in 1797 on the Betsey, a South Sea whaleship under Captain Glasse who was carrying a letter of marque to prey on undefended Spanish coastal shipping off South America. In the Betsey, Tapeooi visited South America and Tonga, and then Port Jackson in February
1800. On the return journey, however, Tapeooi left her to live at Tonga for two years, where he met another Mā'ohi traveller. Late in 1801, Tapeooi joined an ex prize ship, Plumier, going to Fiji, Guam, Manila, Amboyna and Penang. He lived in England from 1807 to 1810 when he set out for Port Jackson as a passenger on the Canada. He found that another Mā'ohi was on the Canada, a seaman named Tomma, who had arrived in London in July 1809 on the Santa Anna, and was now working his passage home. Alas poor Tapeooi died in Sydney in 1812 (Tapeooi ms, ML. ms. A.83 and A.1992: Richards, 1990: 1-14).

Similarly a young Māohi named Mouie left Tahiti in about 1799 and arrived in England early in 1800 where he remained for nearly three years. He returned to Sydney but died there so he too never arrived home (Sydney Gazette 14 August 1803). During 1802 five 'Otahitian youths' aged about 15 were taken to London by the missionary Thomas Haweis . (Haweis papers. ML. ms. 4190, vol. I, 6 September 1802). After a privateering cruise against enemy shipping on the coasts of Peru and Chile, and refitting at Tahiti, the Harrington reached Sydney in March 1805 with a good number of 'Otahitians,' plus some Sandwich Islanders, as members of her crew, while at least five more Mā'ohi were crew on the prize ships taken by the Harrington. Alas none of their Mā'ohi names are recorded ( Sydney Gazette, 10 March 1805).

At Sydney Governor King was very concerned for the safety of such travelling Otahitians, and the impact any mistreatment of them might have on subsequent visits to their home islands. On 26 May 1805 he issued the following proclaimation:

«it is hereby strictly forbid [to be] sending any Otaheitan, Sandwich Islander or New Zealander from this settlement to any island or other part of this coast on any sealing or other voyage, or to any place eastwards of Cape Horn. 'It is to be clearly understood that all such Otaheitans etc are protected in their properties, claims for wages, and [have] the same redress as any of His Majesty's subjects.» (HRA, vol. V: 642; HRNZ 1914, vol. I: 257-258.)

Governor King followed up this humanitarian concern about the condition of the Pacific Islanders in Sydney by inviting all of them, including the Mā'ohi, to assemble at Government House to tell him about their treatment and to assure them of his concern for them (McNab, 1914: 102).

Jorgen Jorgenson, a Danish adventurer, spent seven weeks at Tahiti in mid 1805 where, inciden- 
tally, he met a Peruvian Spaniard fluent in the Mā'ohi language. Before he left, Jorgenson, collected, more or less as ethnological specimens for Joseph Banks, a young Mā'ohi chief and his younger retainer. Much later the missionaries on Tahiti recorded that two other Mā'ohi who had left had on the Alexander, had returned home via Sydney on the Parramatta in July 1807, and that in January 1808 an un-named 'Tahitian returned in the Venus who had gone to England in the Alexander' (Richards, 1996: 135-138; Davies, 1961: 79, 100, 109).

In late July 1806 an unnamed Mā'ohi boatman drowned at Sydney in Hen and Chicken Bay (Sydney Gazette, 27 July 1806.). In April 1807 "two Tahitian youths," or boys, returned to Sydney from England in the Brothers, and were then "sent to their native country," probably in the Parramatta in June 1807 (HRA, vol. VI: 25, 199, 394-395).

A ten year old Mā'ohi boy was brought to London by a missionary and his wife before August 1810 (Chappell, 1996: 127). He had probably been on the Hibernia when the missionaries retreated. They arrived at Sydney, via Fiji, in February 1810. It may well be that other Ma'ohi travelled with them.

Another young Mā'ohi boy called Jem came to Sydney in about 1802 . He was befriended by John MacArthur who sent him to school at Parramatta where Jem learnt to read and write well in English. He was well known to Rev. Samuel Marsden. But after about seven years there, Jem worked his passage to New Zealand in December 1809. No doubt Jem was the unnamed Mā'ohi warrior present during the massacre on the Boyd at Whangaroa in 1810 (Sydney Gazette, 1 September 1810). In 1814 Rev. Marsden, in a ship with 'Dicka-hee, an Otaheitan, and Punnee, a Bolobolan,' met Jem near Whangaroa (Nicholas, 1971 vol. I: 37,92-96; 240-241; vol. II: 209220). Another Mā'ohi, was there too : 'Otaheitian Jack,' who had also become a Maori warrior and chief by 1814 (Richards, 2008: xix).

Several Mā'ohi who reached Sydney were employed in the sealing trade in Bass Strait and south of New Zealand. The first may have been John on the Fly in 1808 (Sydney Gazette, 18 December 1808). In mid winter in 1810 the Santa Anna landed at the inhospitable Bounty Islands a sealing gang including Ruatara, an already experienced Maori seaman, another Maori, two un-named Ma'ohi and ten Europeans. Despite very inadequate supplies, during the next five months the gang took about 8,000 seal skins, but conditions had been so harsh that two men, including one 'Otaheitian,' died there (McNab,
1907: 96; HRNZ, 1914: 338). The other Mā'ohi presumably went on to England in the Santa Anna. Later many other Tahitians went sealing or on trading voyages. The death rate was very high. But quite a few did return home. Other sources not used here indicate that some returnees had a huge impact once they got home.

By 1813 the number of South Sea Islanders engaged in trans-Pacific trade on foreign ships had reached such a volume that the Governor of New South Wales felt obliged to issue further orders cautioning captains not to mistreat local islanders, or to join in their wars. He decreed that no captain was to take away any native unless he chose to go and both his chiefs and his parents approved. The Governor insisted that whenever any islanders were employed, they must be paid fair wages. He also warned that in future any acts of rapine, plunder, piracy, murder and other outrages committed against native people and their property would be punished severely (HRNZ, 1914 vol. I: 429).

In 1817 the British Parliament finally adopted the 'Murders Abroad Act' which included clause that 'all murders or manslaughter committed in the islands of New Zealand and Otaheite... or places not within His Majesty's dominions... shall be tried and punished at any of His Majesty's dominions' (Richards, 2008: 8).

In September 1818 Mary Hassell at Parramatta wrote home to her mother that on 21 May she had had visitors: 'Mr Lawry preacher came with John Henry Master, a religious Tahitian who had lost his right arm in the Battle of Waterloo. He is now to proceed to his home country by the first conveyance with a pension of twenty pounds per year' (ML. ms. A.1677-1673, vol. 3: 514). John Henry Master had probably left Tahiti during 1813, or earlier.

In November 1814 the Surry, Captain Thomas Raine, left Sydney 'for China' and London, 'taking three Otaheitian men and a boy who had once lived with the [mission] brethren' (Marsden papers, ML. ms. A.1995, vol. $4: 48$ ).

In January 1816, Captain Peter Heywood, who had been on HMs Bounty in 1789, was astonished to meet at Gibraltar 'two Otaheitian youths who had been kidnapped and ill-treated on an [English] merchant ship about 13 or 14 months earlier. They had been taken to Lima and Cadiz, where they had escaped into HMS Calypso" (Tagart ML. ms. F. 1597). These two unfortunate men had probably left Tahiti in November or December 1814.

Many other Mā'ohi joined whaleships (Dodge, 1971; Du Pasquier, 1990; Jones, 1986; Lund, 2001). One encountered at Hawaii in 1825 
said that he had 'left Tahiti as a boy to serve on a whaleship'. Afterwards he was in the British Navy, till he was wounded in the Battle of Algiers, [August 1816] when he was discharged as unfit for service, with a pension of twenty five pound per year' (Macrae, 1922: 44).

After 1818 many American whaleships began calling at Tahiti and the Society Islands. Many Mā'ohi joined American crews, some even remaining on board as the whaleships went home. In mid-1825 the "Nantucket Inquirer stated "that about fifty of the natives of Otaheite are employed in whaleships belonging to Nantucket, some of whom are now there. They are a tractable and ingenious" [that is, teachable and clever] (Niles Register, 1 October 1825). Soon after it was reported that some twenty Otaheitians were then at Nantucket (New Bedford Mercury, 7 July 1826; Ward, 1967 vol.7: 13).

Other Mā'ohi soon visited New Bedford and the other New England whaling ports, so that by the 1830s and 1840s the number involved as crewmen and as visitors could have been considerable, perhaps between 500 and 1,000 Mā'ohi men. If Tahiti's population was 50,000 , then 1,000 absentees would be $2 \%$ of the total. It seems that by 1840 between $5 \%$ and $10 \%$ of the eligible adult males were absent on foreign ships. Many, probably most, never returned home.

In conclusion, as noted earlier, an unfortunate limitation of shipping arrivals and departures lists is that they tend to perpetuate nonindigenous, colonial, perspectives of Pacific maritime history. Yet seen from the shore with island perspectives, the arrival of foreign trading and whaling vessels in the Pacific islands before 1825 usually involved an erratic succession of brief, unrelated, visits. Some of these visits introduced the islanders to foreign goods and commerce, but many were of little more than momentary or curiosity value to the people on shore. The prime task that faced the generation of indigenous Pacific Islanders who were alive from 1800 to 1840 , was how to make sense of such a disparate parade of foreign visitors, and how to adapt to their new ideas, new technologies, new religions and their new diseases.

Certainly some big changes followed on shore after only a few ship visits, but the main engines of change were not foreign, but over-whelmingly local. Indeed looking even closer, it can be seen that What Matters is not the timing and length of each early visit, most of which were very short, or the volume of goods and ideas it deposited, but rather the spaces in between visits. What matters is what the local islanders deliberated upon, and decided, and did, in between visits, and in preparation for the next visitors.

In the early culture contact period, what mattered most was the opening of local minds. Astonishment and fear was there too, but more to the point the foreigners prompted among the Mā'ohi massive social changes with new Intellectual Ferment, New Ideas, New Objectives and New Potentials. The immediate and continuing 'shocks' that hit island systems certainly sparked off massive cataclysmic social and political changes. But I think that looking more widely at these shipping lists brings us to see the Islanders much more as participants driving the process from inside. Certainly the Islanders were not just pawns in this massive invasion and time of massive social change. It was the islanders themselves who led the changes, not the transient, erratic, foreign visitors.

\section{BIBLIOGRAPHY}

Bligh William, 1792. A Voyage to the South Seas in HMS Bounty, London, George Nichol.

Chappell David A., 1967. Double Ghosts: Oceanic Voyagers on EuroAmerican Ships, New York, Armonk, M.E. Sharpe.

Corney Bolton G., 1913, 1915 and 1919. The Quest and Occupation of Tahiti... in the years 1772-1776, 3 vols, London, Hakluyt Society.

Cumpston John, 1964. Shipping Arrivals and Departures, Sydney, 1788-1825, Canberra, Roebuck Society.

DAVIES John, 1961. The History of the Tahiti Mission 1799-1830, written by John Davies and edited by C.W., Newbury, Cambridge, Hakluyt Society.

DiLlon Peter, 1829. Narrative and Successful Result of a Voyage in the south seas, 2 vols, London.

Dodge Ernest, 1971. Whaling Off Tahiti, Paris, Société des Océanistes, dossier 11.

Hassell Mary, ms. ms papers A.1677-3, vol. 3: 514, Sydney, Mitchell Library, Hassell Papers.

Haweis Rev T., ms. Ms 4190, vol. I, 6 September 1802, Sydney, Mitchell Library, Haweis Papers.

Historical Records of Australia (HRA), Australia, Government Printer.

Historical Records of New Zealand (HRNZ), 1914. 2 vols, Wellington, Government Printer.

Jones A.G.E., 1986. Ships Employed in the South Seas Trade 1775-1861, Canberra, Roebuck Society.

LANGDON Robert, 1978. American Whalers and Traders in the Pacific: A Guide to Records on Microfilm, Canberra, ANU, Pacific Manuscripts Bureau.

-, 1979. Thar She Went: An Interim Index to the Pacific Islands Visited by American Whalers and Traders in the $19^{\text {th }}$ Century, Canberra, ANU, Pacific Manuscripts Bureau. 
- 1984. Where The Whalers Went. An Index to the Pacific Ports and Islands Visited by American Whalers (and some other ships) in the $19^{\text {th }}$ century, Canberra, ANU, Pacific Manuscripts Bureau.

Lund Judy, 2001. Whaling Masters and Whaling Voyages Sailing From American Ports. A Compilation of Sources, New Bedford Whaling Museum and Kendall Whaling Museum.

MaCrae James, 1922. With Lord Byron at the Sandwich Islands in 1825..., Honolulu, W.F. Wilson.

MCNAB Robert, 1907 (Ed. 1909). Murihiku and the Southern Islands, Invercargill.

—, 1914. From Tasman to Marsden, Dunedin.

Marsden Rev S., ms. MS. A.1995, vol. 4: 48, Sydney, Mitchell Library, Marsden Papers.

Newbury C.W., 1961. The History of the Tahitian Mission 1799-1830, Cambridge, Hakluyt Society.

NiCHOLAS John, 1971 (reprinted). Narrative of a Voyage to New Zealand..., 2 vols, Auckland, Wilson and Horton.

PASQUIER Thierry (Du), 1990. Les Baleiniers francais au XIX ${ }^{e}$ siecle, Grenoble, Terre et Mer.

PMB, Pacific Manuscripts Bureau, Canberra, Australian National University.

RICHARDS Rhys, 1990. Indigenous Beachcombers: The Case of Tapeooe, a Tahitian Traveller from 1798 to 1812, The Great Circle 12, pp. 1-14.

—, 1996. Jorgen Jorgenson's Observations on Pacific Trade; and Sealing and Whaling in Australian and
New Zealand Waters before 1805, Wellington, Paremata Press and Te Taa Haeretahi Press.

- 2000. Honolulu: Centre of Trans-Pacific Trade: Shipping Arrivals and Departures 1820 to 1840, Canberra, ANU, Pacific Manuscripts Bureau.

RichARDS Rhys and Robert LANGDON, 2008. Tahiti and the Society Islands Shipping Arrivals and Departures 1767 to 1852, Canberra, ANU, Pacific Manuscripts Bureau, and Jean-Louis Boglio Maritime Books, 257 p.

TAgart, ms. Papers. MS. F.1597, Sydney, Mitchell Library.

TAPEOOE, ms. See Richards, 1990.

Turnbull John, 1805. A Voyage Around the World in the years 1800 to 1804,3 vols, London.

VAnCOUVER George, 1803. A Voyage of Discovery to the North Pacific Ocean..., 6 vols, London, (Reprinted in 1984 edited by W. Kaye Lamb, London Hakluyt Society).

WARD Gerrard R., 1966. American Activities in the Central Pacific 1790-1870, 8 vols, Ridgewood (New Jersey), Gregg Press.

WiLson William, 1799. A Missionary Voyage to the Southern Pacific Ocean...1796...1798 in the ship Duff..., London.

Wright R., 1986. The Forgotten Generation of Norfolk Island and Van Diemen's Land, Sydney, Library of Australian History. 
